\title{
İlkbahar Ekim Döneminde Farklı Ekim Tarihlerinin Arı Otunun (Phacelia tanacetifolia Bentham) Tohum Verimi İle İlgili Özellikleri Üzerine Etkileri
}

\author{
Ayşe GENÇ LERMi ${ }^{1}$ * Ş̧ahin PALTA ${ }^{2}$ \\ ${ }^{1}$ Bartın Üniversitesi, Meslek Yüksek Okulu, Bartın / Türkiye \\ ${ }^{2}$ Bartın Üniversitesi, Orman Fakültesi, Bartın / Türkiye \\ *Sorumlu yazar: agenclermi@ bartin.edu.tr
}

Geliş Tarihi: 22.07.2016

Kabul Tarihi:21.02.2017

Özet: $\mathrm{Bu}$ araştırmanın amacı, Bartın ili ve benzer iklim koşullarına sahip bölgelerde arı otu bitkisinin tohum amaçlı yetiştiriciliği için ilkbahar ekim döneminde en uygun ekim tarihinin belirlenmesidir. Araştırma Bartın ilinin Akmanlar köyünde tesadüf blokları deneme desenine göre üç tekrarlamalı olarak kurulmuştur. Araştırma sonuçlarına göre en yüksek tohum verimi $96 \mathrm{~kg} \mathrm{da}^{-1}$, hasat indeksi \% 5.92 ve bin tane ağırlığı $1.65 \mathrm{~g}$ ile 1 Mart ekim tarihi uygulamasından elde edilmiştir. Biyolojik verim ve saman verimine ait en yüksek değerler 1 Mart, 15 Mart ve 1 Nisan ekim tarihi uygulamalarından elde edilmiştir. Arı otunun tohum amaçlı yetiştiriciliği için ilkbaharda iklim koşullarına göre ekimin geciktirilmeden mart başı ile nisan başı arasında yapılması önerilmektedir.

Anahtar Kelimeler: Arı otu, ekim zamanı, tohum verimi, biyolojik verim, hasat indeksi

\section{The Effect Of Different Sowing Dates on Seed Yield Characteristics Of Phacelia (Phacelia tanacetifolia Bentham ) in Spring Sowing Period}

Abstract: The aim of this research is to determine the most suitable dates for seed production of phacelia in Bartın province and similar ecology in spring sowing period. The study was arranged in completely randomized block with three replications in Akmanlar village of Bartın. Acording to the results it was obtained that the highest seed yield was $96 \mathrm{~kg} \mathrm{da}^{-1}$, the highest harvest index was $5.92 \%$ and the highest thousand kernel weight was $1.65 \mathrm{~g}$ in 1 March sowing date aplication. The highest biolocigal yield and hay yield were obtained from 1 March, 15 March and 1 April sowing date aplications. It is suggested that sowing for seed cultivation of phacelia should be made without delay between the begining of march and begining of april based on climate contidions in spring.

Keywords: Phacelia, sowing date, seed yield, biological yield, harvest index

\section{Giriş}

Kaba yem teminindeki dar boğaz hayvancılığımızı doğrudan etkilemektedir. Hayvancilık faaliyetlerindeki azalmanın artan bir ivmeye dönüştürülmesi kaliteli kaba yem üretiminin artması ile sağlanabilir. Yem temininde ilk akla gelen çayır ve meralarımız, değeri ve önemi bilinmeden kullanıma maruz kalmıştır. Bilinçsiz ve aşırı otlatma nedeniyle bugün meralardan istenilen verim ve kalitede yem üretimi gerçekleşememektedir. Meralar üzerindeki baskıyı azaltmak ve yem ihtiyacını karşılamak için tek çıkış yolu yem bitkileri üretiminden geçmektedir. Yem bitkileri tarımı, tarımsal faaliyetler içerisindeki önemi ile bitkisel ve hayvansal üretimin sigortasıdır (Soya ve ark., 2004).

Kuşvuran ve ark. (2011), Tarım Bakanlığ1 tarafından yapılan desteklemelerle son yıllarda yem bitkileri ekim alanlarının artış göstererek \% 9.5 düzeylerine çıktığını ancak gelişmiş ülkeler seviyesine hala ulaşamadığını bildirmektedir. Aynı araştırıcılar ülkemizde yapılan yem bitkileri üretiminde verim potansiyellerinin düşük olduğunu ayrıca tohum üretimi ve temininde de zorluklar yaşandığını belirlemişlerdir. $\mathrm{Bu}$ zorlukların aşılabilmesi için üreticilerimizin yem bitkilerinin önemi konusundaki bilgi ve tecrübe eksikliğinin giderilmesi için, bakanlıkça uygulanan üretim teşviklerinin yanında eğitim ve yayım faaliyetlerinin de yer alması gerekmektedir.

Batı Karadeniz bölgesinde yem bitkileri ekim alanı 195.546 ha olup toplam ekim alanları içerisinde \% $12.11^{\prime}$ lik bir orana sahiptir. Yem bitkileri ekim alanı içerisinde 130.248 ha'lik alanda en fazla \% 22.55'lik oran ile fiğ yetiştiriciliği yapılmakta olup bunu 32.142 ha ekim alanı ve \% 12.32'lik oran ile silajlık mısır takip etmiştir. Aynı araştırıcılar Batı Karadeniz bölgesinde hayvan varlığının 1.1 milyon BBHB'ye 
eşdeğer olduğunu ve hayvan varlığının y1llık kaba yem ihtiyacinın $(1.1 \times 4.5=4.95$ milyon ton) yaklaşık 5 milyon ton kaba yem olduğunu belirtmiştir. Çayır mera alanın 782.256 ha olduğunu, bu alanlardan y1lda ortalama olarak 1-1.5 milyon ton ve 195.546 ha toplam yem bitkileri alanından ise yaklaşık 500 bin ton kuru kaba ot üretildiği belirtilmiştir. Böylece yaklaşık 1.5-2 milyon ton üretilen kuru otun, bölgenin büyükbaş hayvan varlığının kaba yem ihtiyacının yarısından daha azını karşılayabildiği bildirilmiştir. Ayrıca bölgenin ekolojisine uyum sağlayacak yem bitkisi tür ve çeșitlerinin belirlenmesi amaciyla üniversiteler, kamu kuruluşları ve özel sektör işbirliği ile araştırmaların yapılması ve elde edilen sonuçların üreticiler ile paylaşılması gerektiğini vurgulanmıştır (Kuşvuran ve ark., 2011).

Ünal (2004), tohumluğun yem bitkileri üretiminde en önemli girdilerden biri olduğunu, yem bitkileri üretiminin geliştirilmesinin tohumluk üretimi ve pazarlama sorunlarının çözülmesi ile mümkün olduğunu belirtmiştir. Araştırıcı dünya tohum ticaretinde lider ülkelerin ortak özelliğinin, araştırma çalışmalarına önem vermeleri ve özel sektöre öncelik tanımaları olduğunu, ülkemizde de yem bitkileri ekim alanlarının artırılması için en önemli şartın tohumluk üretiminden geçtiğini bildirmektedir.

Yem bitkileri üretiminde yonca, fiğg, silajlı mısır gibi türlerin yetiştirilme oranı yüksektir. Bu bitkilere ek olarak bölge ekolojisine uygun olabilecek alternatif yem bitkilerinin potansiyellerinin ortaya konularak değerlendirilme olanaklarının araştırılması gerekmektedir. Genç Lermi ve Palta (2014), Bartın ilinde yürüttükleri araştırmada, bölgede yürütülen tarımsal faaliyetlere birçok yönden cevap verebilecek ar1 otu bitkisinin hem kaba yem hem de ar1 meras1 olarak önemli bir potansiyele sahip olduğunu belirtmiştir.

Kumova ve Korkmaz (1998), Ar1 otunun değişik iklim bölgelerinde adaptasyonu konusunda çalışmalar yapıldığını ve başta Almanya olmak üzere birçok Avrupa ülkesinde erken ve geç ilkbahar dönemlerinde çalışmalar yapıldığını bildirmektedir. Karadağ ve Büyükburç
(1999), Tokat Kazova koşullarında arı otunun ilkbahar ekim periyodunda verim ve adaptasyonu üzerine yürüttükleri araştırmada, biyolojik verimi birinci yılda $484.31 \mathrm{~kg} / \mathrm{da}$, ikinci yılda $190.81 \mathrm{~kg} / \mathrm{da}$, tohum verimini birinci y1lda $9.84 \mathrm{~kg} / \mathrm{da}$ ikinci yılda $6.06 \mathrm{~kg} / \mathrm{da}$ olarak elde etmiştir. Ayrica biyolojik verim ile tohum verimi arasında olumlu ve önemli bir ilişki tespit etmiştir.

Karadağ ve Büyükburç (2003), Tokat koşullarında arı otunun yazlık ekim zamanında tohum verimi ve özelliklerini inceledikleri çalışmalarında, 5 Mart tarihinden itibaren on beșer gün aralıklarla dört farklı tarihte ekim yapmışlardır. Elde ettikleri iki yıllık ortalama sonuçlara göre en yüksek biyolojik verimi $477.1 \mathrm{~kg} / \mathrm{da}$ ile 5 Mart ekim tarihinden, en yüksek tohum verimi surasiyla 14.9 ve $11.7 \mathrm{~kg} / \mathrm{da}$ ile 5 Mart ve 20 Mart ekim tarihlerinden, benzer şekilde saman verimin de de en yüksek değerler $462.2 \mathrm{~kg} / \mathrm{da}$ ve $411.2 \mathrm{~kg} / \mathrm{da}$ ile ilk iki ekim tarihinden elde etmiştir. Bin tane ağırlığ bakımından ilk üç ekim zamanı aynı grupta yer almış ve son ekim tarihinden daha düşük değerlere ulaşmıștır. Araştırıcılar farklı ekim zamanına ait özellikler arasındaki ikili ilişkileri irdelemişlerdir. Elde ettikleri sonuçlara göre biyolojik verim ile tohum verimi arasında denemenin ikinci yılında olumlu ve önemli bulduklarını, bin tane ağırlığını birinci yıl olumlu ve önemli, saman verimi ile her iki yılda da olumlu ve çok önemli ilişki tespit etmiştir. Ayrıca tohum verimi ile saman verimi ve bin tane ağırlığı arasında ikici yıl pozitif ve önemli ilişki olduğunu belirlemişlerdir. Araştırıcılar sonuç olarak arı otunun ilkbahar döneminde tohum amaçlı yetiştiriciliğinde en uygun ekim zamanının Mart ayının ilk haftası olduğunu ekim geciktikçe verimin düştüğünü saptamışlardır.

$\mathrm{Bu}$ araştırmada arı otu bitkisinin ilkbahar ekim periyodunda tohum verimi ve verimle ilgili özellikleri bakımından en uygun ekim tarihinin belirlenmesi amaçlanmıştır. 


\section{Materyal ve Yöntem}

Araştırma, 2013-2014 yıllarının ilkbahar ekim periyotlarında Bartın ilinin Akmanlar köyünde yürütülmüştür. Akmanlar köyü 41.547253 kuzey enleminde 32.248848 doğu boylamında yer almaktadır, denizden yüksekliği 58 m'dir (Şekil 1). Araştırmanın yürütüldüğü alanın ortalama toprak özellikleri; killi, orta derecede kireçli $(7.01 \%$
$\mathrm{CaCO}_{3}$ ), organik maddece zengin $(3.20 \%)$, azot varlığ $\% 0.29$, hafif alkali $(\mathrm{pH} 7.54)$ olarak belirlenmiştir.

Araştırmanın yapıldığı yıllara ve uzun yıllar ortalamasına ait yağış verileri grafik olarak Şekil 2.'de, sıcaklık ve yağış değerleri ise Tablo 1.'de verilmiştir. Uzun yıllar sıcaklık ortalaması $11.40 \mathrm{C}$, nem değeri ise \% 78.5'dir (Genç Lermi ve Palta, 2014).

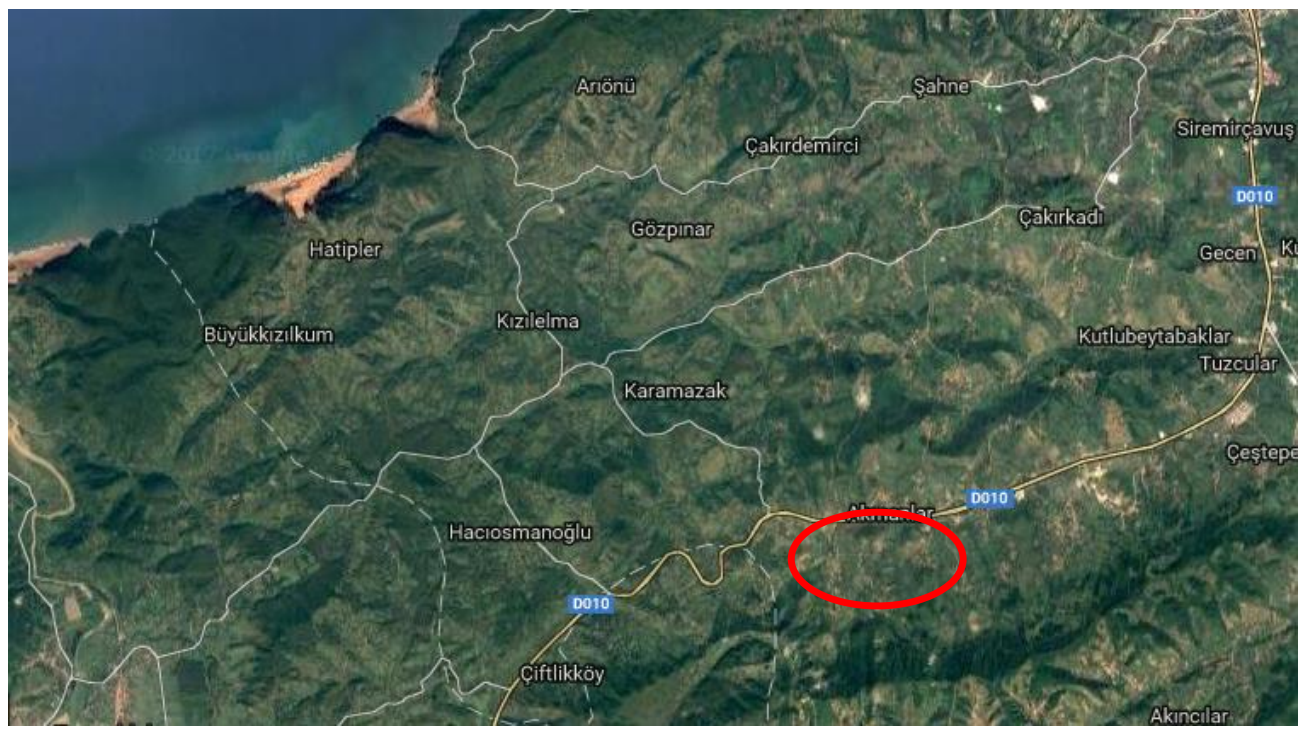

Şekil 1. Araştırmanın yapıldığı köye ait uygu görüntüsü

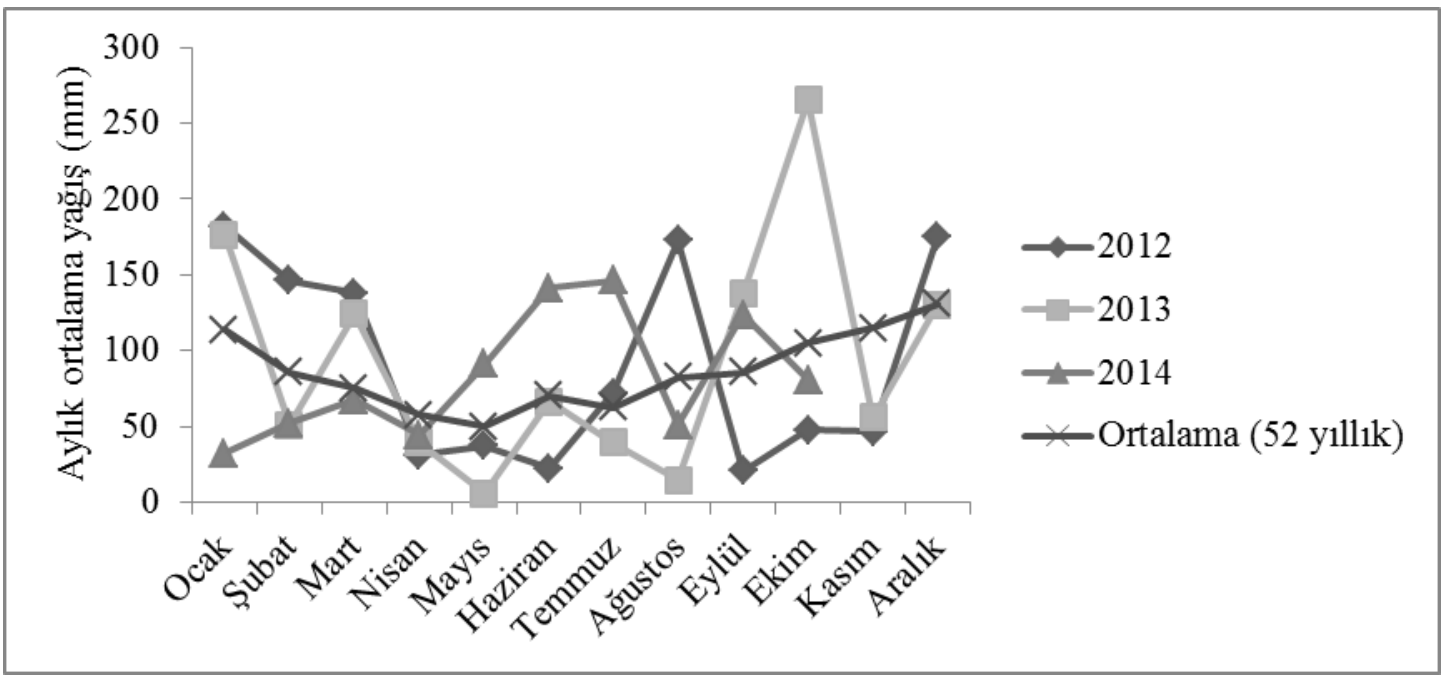

Şekil 2. Araştırmanın yapıldığı ilin 2012, 2013, 2014 ve uzun yıllar ortalamasına ait aylık yağış verileri (Genç Lermi ve Palta, 2014). 
Tablo 1. Bartın ili aylık ve uzun yıllar ortalamasına ait sıcaklık ve yağış değerleri

\begin{tabular}{lcccccccc}
\hline & \multicolumn{3}{c}{ Sicaklık ('C) } & \multicolumn{5}{c}{ Yağıs (mm) } \\
\hline AY / YIL & $\mathbf{2 0 1 2}$ & $\mathbf{2 0 1 3}$ & $\mathbf{2 0 1 4}$ & $\begin{array}{r}\text { Ortalama } \\
\text { (50 Yıllı) }\end{array}$ & $\mathbf{2 0 1 2}$ & $\mathbf{2 0 1 3}$ & $\mathbf{2 0 1 4}$ & $\begin{array}{c}\text { Ortalama } \\
\text { (52 Yıllık) }\end{array}$ \\
\hline Ocak & 2,7 & 5,1 & 6,2 & $\mathbf{4 , 1}$ & 182,1 & 176,6 & 32,1 & $\mathbf{1 1 3 , 5}$ \\
Şubat & 1,5 & 7,5 & 6,4 & $\mathbf{4 , 7}$ & 146,2 & 50,9 & 52,0 & $\mathbf{8 5 , 4}$ \\
Mart & 4,8 & 9,4 & 8,5 & $\mathbf{7 , 0}$ & 138,0 & 124,1 & 67,6 & $\mathbf{7 5 , 2}$ \\
Nisan & 13,7 & 12,3 & 12,4 & $\mathbf{1 1 , 2}$ & 31,2 & 39,2 & 44,2 & $\mathbf{5 7 , 4}$ \\
Mayıs & 16,5 & 17,7 & 16,5 & $\mathbf{1 5 , 6}$ & 37,4 & 5,8 & 91,1 & $\mathbf{5 0 , 0}$ \\
Haziran & 21,9 & 20,9 & 20,1 & $\mathbf{1 9 , 8}$ & 22,4 & 66,6 & 141,2 & $\mathbf{7 0 , 4}$ \\
Temmuz & 24,2 & 22,6 & 23,2 & $\mathbf{2 2 , 1}$ & 71,7 & 39,6 & 146,3 & $\mathbf{6 2 , 6}$ \\
Ağustos & 22,1 & 22,9 & 23 & $\mathbf{2 1 , 6}$ & 172,5 & 14,4 & 50,9 & $\mathbf{8 2 , 6}$ \\
Eylül & 18,6 & 17,2 & 18,4 & $\mathbf{1 7 , 7}$ & 20,9 & 137,6 & 123,6 & $\mathbf{8 5 , 7}$ \\
Ekim & 16,1 & 11,4 & 14,5 & $\mathbf{1 3 , 7}$ & 47,7 & 265,3 & 80,9 & $\mathbf{1 0 4 , 9}$ \\
Kasım & 11,0 & 9,7 & - & $\mathbf{9 , 1}$ & 46,8 & 56,1 & - & $\mathbf{1 1 5 , 0}$ \\
Aralık & 7,0 & 2,3 & - & $\mathbf{6 , 0}$ & 175,6 & 130,2 & - & $\mathbf{1 3 1 , 0}$ \\
\hline
\end{tabular}

İlkbahar ekim periyodunda 6 farklı ekim tarihi uygulanan araștırma tesadüf blokları deneme desenine göre üç tekrarlamalı olarak yürütülmüştür. İlkbahar ekimleri Mart ayından itibaren 15'er gün aralıkla 1 Mart, 15 Mart, 1 Nisan, 15 Nisan, 1 Mayis, 15 May1s tarihlerinde gerçekleştirilmiştir. Arı otunun ilkbahar ekim periyodunda tohum veriminin belirlenmesi amacıyla yürütülen bu araştırma her bir parsel $5 \mathrm{mx} 2 \mathrm{~m}\left(10 \mathrm{~m}^{2}\right)$ olmak üzere toplam 18 parselden oluşmaktadır. Denemenin yürütüldüğü her iki yılda da 15 Mayıs tarihinde yapılan ekimlerde sulama yapılmasına rağmen çıkış sağlanamamıştır. Sira aras1 mesafesi $40 \mathrm{~cm}$ olarak uygulanmıștır. Parsellere atılacak tohum miktarı dekara $2 \mathrm{~kg}$ hesabıyla belirlenmiştir (Karadağ ve Büyükburç, 2003). Çıkış sağlanana kadar sulama yapılmıştır. Çıkıştan sonra vejetasyon süresince su ihtiyacı doğal yağgşlarla karşılanmıştır. Ekimle birlikte 10 $\mathrm{kg} / \mathrm{da}$ hesabiyla DAP (diamonyum fosfat) gübresi verilmiştir. Denemede hastalıklara, zararlılara ve yabancı otlara karşı kimyasal mücadele yapılmamıştır, yabancı ot mücadelesi elle yapılmıştır. Ölçüm işlemleri ve hasat her parselin iki yanlarındaki sıralardan ve parsel başlarından 0.5 'er $\mathrm{m}$ kenar tesiri birakıldıktan sonra (parselin yarısında) $1 \mathrm{~m}^{2}$ lik kuadrat ile yapılmıştır. Bitki materyali olarak İtalyan orijinli "Stala" çeşidi kullanılmıştır.

Biyolojik verim $\left(\mathrm{kg} \mathrm{da}^{-1}\right)$, tohum verimi

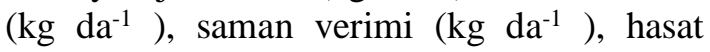

indeksi (\%) ve bin tane ağırlığı (g) Karadağ ve Büyükburç (2003), Kızılşimşek ve Ateş (2004)'ün önerdiği yöntemlere göre belirlenmiştir.

Deneme sonuçlarından elde edilen veriler İstatistik Analiz Sistemleri (SAS) programının Genel Linear Model esası ile \% 5 ve \% 1 önemlilik düzeylerine göre değerlendirilmiştir (Anonymous, 1988). Arı otunun bazı bitkisel özellikleri arasındaki ilişkileri belirlemek için iki yıllık ortalama değerleri kullanılarak Pearson korelasyon analizi yapılmıştır. İstatistiki analiz SPSS 16.0 yazılım programı kullanılarak yapılmıştır (SPSS 16.0, 2007).

\section{Bulgular ve Tartışma}

Ar1 otu bitkisinin ilkbahar ekim dönemi verim ve verim öğelerine ait 2013, 2014 ve her iki yılın birleştirilmiş ortalamalarına ait değerler Tablo 2.'de verilmiştir. Yapılan istatistiki analizlere göre her iki y1lda da ekim tarihi uygulamaları arasında farklılıklar önemli bulunmuştur. 2013 yilında biyolojik verim, tohum verimi, saman verimi ve hasat indeksi ortalamaları bakımından en yüksek değerler ilk ekim tarihi olan 1 Mart ekim tarihi uygulamasından elde edilmiş̧ir. 1 Mart ekim tarihinden sonraki ekim tarihlerinde ekim tarihi geciktikçe değerler de düşmüştür. En düşük değerler ise incelenen tüm özelliklerde son ekim tarihi olan 1 Mayis uygulamasından elde edilmiştir. 
Araştırmanın yürütüldüğü ikinci yıl en yüksek biyolojik verim ve saman verimi 15 Mart ve 1 Nisan ekim zamanlarından elde edilmiştir. Ancak tohum verimi, hasat indeksi ve bin tane ağırlığı bakımından en yüksek değerler 1 Mart ekim zamanından elde edilmiştir (Tablo 2). 2014 y1lında mart sonu nisan başındaki biyolojik verim değerlerinin yüksek olması bu yılda mayıs, haziran ve temmuz aylarında düşen yağışın hem 2013 y1lı değerlerinden hem de uzun y1llar ortalama değerlerinden oldukça yüksek olmasından kaynaklanmıştır (Şekil 2). Ekim yapıldıktan sonra vejetatif büyüme döneminde bol yağıș alması bitkinin daha fazla biyokütle oluşturmasını sağlamıştır. Buna karşılık aynı ekim tarihi uygulamalarında tohum verimlerinin düşük olmas1 ise generatif dönemde de yağışların devam etmiş olmasından kaynaklanmış olabilir.

İki yıllık ortalama değerlere göre biyolojik verim bakımından 1 Mart, 15 Mart ve 1 Nisan uygulamaları arasında istatistiki olarak fark görülmemiş ve en yüksek değerler bu uygulamalarda sirasılya; 1550 , 1530 ve $1532 \mathrm{~kg} \mathrm{da}^{-1}$ olarak elde edilmiștir. Tohum verimi bakımından $96 \mathrm{~kg} \mathrm{da}^{-1}$ ile 1 Mart uygulamasindan, saman verimi ise 1454,1463 ve $1489 \mathrm{~kg} \mathrm{da}^{-1}$ ile sirasiyla 1 Mart, 15 Mart ve 1 Nisan uygulamalarından elde dilmiştir. Hasat indeksi \% 5.92 ve bin tane ağırlığında $1.65 \mathrm{~g}$ ile en yüksek 1 Mart uygulamasından elde edilmiştir.

Ar1 otu bitkisinin ilkbahar dönemi ekimleri için ortalama değerler biyolojik verimi $1313 \mathrm{~kg} \mathrm{da}^{-1}$, tohum verimi $51 \mathrm{~kg} \mathrm{da}^{-1}$, saman verimi $1262 \mathrm{~kg} \mathrm{da}^{-1}$, hasat indeksi \%
3.78 , bin tane ağırlığ ise $1.34 \mathrm{~g}$ olarak tespit edilmiştir. Karadağ ve Büyükburç (2003), arı otu bitkisinde ilkbahar döneminde arı otunun tohum verimi üzerine etkilerini belirlemek amacıyla dört farklı ekim tarihi uygulamıştır. Araştırıcılar iki yıllık ortalama sonuçlara göre en yüksek biyolojik verimi $477.1 \mathrm{~kg} \mathrm{da}^{-1}$ ile 5 Mart ekim tarihinden, en yüksek tohum verimi sirasiyla 14.9 ve $11.7 \mathrm{~kg} \mathrm{da}^{-1}$ ile 5 Mart ve 20 Mart ekim tarihlerinden, saman veriminde de en yüksek değerleri $462.2 \mathrm{~kg}$ $\mathrm{da}^{-1}$ ve $411.2 \mathrm{~kg} \mathrm{da}^{-1}$ ile yine ilk iki ekim tarihinden elde etmiştir. Karadağ ve Büyükburç (1999), aynı ekolojik bölgede yürüttükleri bir başka araștırmada, arı otunun ilkbahar ekim periyodunda biyolojik verimini birinci yılda 484.31, ikinci yılda $190.81 \mathrm{~kg}$ $\mathrm{da}^{-1}$ ve tohum verimini birinci y1lda $9.84 \mathrm{~kg}$ $\mathrm{da}^{-1}$, ikinci y1lda $6.06 \mathrm{~kg} \mathrm{da}^{-1}$ olarak elde etmiş̧ir. Araştırıcıların elde ettiği sonuçlar araştırmamızdan elde edilen sonuçlara göre daha düşüktür. $\mathrm{Bu}$ farklılık denemelerin yürütüldüğ̈̈ bölgelerdeki yıllık yağış, sicaklık fark1 ve kullanılan tohumluk çeşidinin farklığından kaynaklanmış olabilir (Tablo 1.). Kızılşimşek ve Ateş (2004), arı otunun tohum dökme özelliğinden dolayı, tohum veriminin belirlenmesinde hasat tekniği ve zamanının önemli olduğunu bildirmektedir. Araştırmamızın bir diğer kısmında ar1 otunun ar1 meras1 olarak kullanımı olanaklarının değerlendirilmesi amaciyla deneme alanına arı kolonileri yerleştirilmiştir. Bu durum da aynı çalışmada tohum veriminin artmasına katkıda bulunmuş olabilir. 
Tablo 2. Beş farklı ekim zamanının arı otunun biyolojik verim, tohum verimi, saman verimi, hasat indeksi ve bin tane ağırlığına etkisine ilişkin ortalamalar

\begin{tabular}{|c|c|c|c|c|c|}
\hline & $\begin{array}{l}\text { Biyolojik } \\
\text { Verim } \\
\left(\mathrm{kg} \mathrm{da}^{-1}\right)\end{array}$ & $\begin{array}{l}\text { Tohum } \\
\text { Verimi } \\
\left(\mathrm{kg} \mathrm{da}^{-1}\right)\end{array}$ & $\begin{array}{l}\text { Saman } \\
\text { Verimi } \\
\left(\mathrm{kg} \mathrm{da}^{-1}\right)\end{array}$ & $\begin{array}{l}\text { Hasat } \\
\text { indeksi \% }\end{array}$ & $\begin{array}{l}\text { Bin tane } \\
\text { Ağırlığı (g) }\end{array}$ \\
\hline & \multicolumn{5}{|c|}{2013} \\
\hline 1 Mart & $1500 a^{* * *}$ & $95 \mathrm{a}^{* *}$ & $1405 \mathrm{a}^{* *}$ & $6.30 a^{* *}$ & $1.59 a^{* *}$ \\
\hline 15 Mart & $1240 b$ & $63 b$ & $1177 b c$ & $5.12 \mathrm{~b}$ & $1.53 \mathrm{a}$ \\
\hline 1 Nisan & $1220 \mathrm{~b}$ & $31 \mathrm{c}$ & $1189 b$ & $2.55 \mathrm{c}$ & $1.33 \mathrm{~b}$ \\
\hline 15 Nisan & $1133 c$ & $20 \mathrm{~d}$ & $1113 c$ & $1.82 \mathrm{c}$ & $1.15 \mathrm{c}$ \\
\hline 1 Mayıs & $973 d$ & $17 \mathrm{~d}$ & $957 \mathrm{~d}$ & $1.72 \mathrm{c}$ & $1.03 \mathrm{~d}$ \\
\hline Ort & $1213 \mathrm{~B}^{* * *}$ & $45 \mathrm{~B} * *$ & 1168B & $3.50 \mathrm{~B}^{* * *}$ & $1.32 \mathrm{~A}^{*}$ \\
\hline \multirow[t]{2}{*}{ LSD } & 71.94 & 3.71 & 72.82 & 1.07 & 0.07 \\
\hline & \multicolumn{5}{|c|}{2014} \\
\hline 1 Mart & $1600 b^{* *}$ & $98 \mathrm{a}^{* *}$ & $1502 b^{* *}$ & $6.10 a^{* *}$ & $1.73 a^{* *}$ \\
\hline 15 Mart & $1819 a$ & $70 \mathrm{~b}$ & $1750 \mathrm{a}$ & $3.84 \mathrm{~b}$ & $1.6 \mathrm{~b}$ \\
\hline 1 Nisan & $1843 \mathrm{a}$ & $54 \mathrm{c}$ & $1789 a$ & $2.9 \mathrm{c}$ & $1.36 \mathrm{c}$ \\
\hline 15 Nisan & $1083 c$ & $37 d$ & $1047 \mathrm{c}$ & $3.39 \mathrm{cb}$ & 1.10 \\
\hline 1 Mayıs & $719 d$ & $29 \mathrm{~d}$ & $690 \mathrm{~d}$ & $4.08 \mathrm{~b}$ & 1.03 \\
\hline Ort & $1413 \mathrm{~A}$ & $58 \mathrm{~A}$ & $1356 \mathrm{~A}$ & $4.06 \mathrm{~A}$ & $1.36 \mathrm{~B}$ \\
\hline \multirow[t]{2}{*}{ LSD } & 146.7 & 8.60 & 149.93 & 1.02 & 0.09 \\
\hline & \multicolumn{5}{|c|}{ Birleștirilmiş yıllar } \\
\hline 1 Mart & $1550 a^{* * *}$ & $96 a^{* *}$ & $1454 a$ & $5.92 \mathrm{a}^{* *}$ & $1.65 \mathrm{a}$ \\
\hline 15 Mart & $1530 \mathrm{a}$ & $67 \mathrm{~b}$ & $1463 a$ & $4.48 \mathrm{~b}$ & $1.57 \mathrm{~b}$ \\
\hline 1 Nisan & $1532 \mathrm{a}$ & $43 c$ & $1489 a$ & $2.72 \mathrm{c}$ & $1.35 \mathrm{c}$ \\
\hline 15 Nisan & $1108 b$ & $29 d$ & $1080 \mathrm{~b}$ & $2.60 \mathrm{c}$ & $1.12 \mathrm{~d}$ \\
\hline 1 Mayıs & $847 \mathrm{c}$ & $23 e$ & $824 c$ & $2.90 \mathrm{c}$ & $1.04 \mathrm{e}$ \\
\hline Ort & 1313 & 51 & 1262 & 3.78 & 1.34 \\
\hline C.V. & 4.66 & 6.84 & 4.96 & 5.11 & 3.02 \\
\hline
\end{tabular}

$* p<0.005, * * p<0.001$

Ar1 otunun ilkbahar ekim döneminde farklı ekim tarihi uygulamalarında incelenen özelliklerin birbirleri ile ilişkilerinin ortaya koyulması amaciyla korelasyon analizi yapılmıştır. Analiz sonuçlarına göre biyolojik verim ile tohum verimi $(r=0.673)$, saman verimi $(r=0.998)$ ve bin tane ağırlığ $(r=0.756)$ arasında istatistiki olarak anlaml pozitif ilişkiler bulunmuştur. (Tablo 3). Biyolojik verim ile tohum verimi arasında pozitif ve önemli bir ilişkinin bulunduğu bazı araştırıcılar tarafından da bildirilmiştir
(Karadağ ve Büyükburç, 2003; Karadağ ve Büyükburç, 1999). Biyolojik verim ve saman verimi arasındaki bulunan ilişki, Karadağ ve Büyükburç (2003) tarafindan da olumlu ve önemli bulunmuştur. Tohum verimi ile hasat indeksi $(r=0.876)$, saman verimi $(r=0.626)$ ve bin tane ağırlığı $(r=0.910)$ arasında pozitif ve önemli bir ilişki ortaya çıkmıştır. Hasat indeksi ile bin tane ağırlığ $(r=0.698)$ arasında, saman verimi ile bin tane ağırlığ $(r=0.721)$ arasında önemli ve pozitif ilişkiler belirlenmiştir. 
Tablo 3. Beş farklı ekim tarihinde arı otunun biyolojik verim, tohum verimi, hasat indeksi, saman verimi ve bin tane ağırlıklarının birbirleri ile ilişkisine ait korelasyon değerleri

\begin{tabular}{lcccc}
\hline & $\begin{array}{c}\text { Tohum } \\
\text { Verimi }\end{array}$ & $\begin{array}{c}\text { Hasat } \\
\text { Indeksi }\end{array}$ & $\begin{array}{c}\text { Saman } \\
\text { Verimi }\end{array}$ & $\begin{array}{c}\text { Bin Tane } \\
\text { Ăğı̆lı̆ı }\end{array}$ \\
\hline Biyolojik Verim & $0.673^{* *}$ & 0.300 & $0.998^{* *}$ & $0,756^{* *}$ \\
\hline Tohum Verimi & & $0.876^{* *}$ & $0.626^{* *}$ & $0,910^{* *}$ \\
\hline Hasat İndeksi & & & $0.243^{* *}$ & $0,698^{* *}$ \\
\hline Saman Verimi & & & & $0,721^{* *}$ \\
\hline
\end{tabular}

$* p<0.05, * * p<0.01$.

\section{Sonuç ve Öneriler}

Ar1 otunun farkl1 ekim tarihi uygulamalarında, iki yıllık ortalamalara göre en yüksek biyolojik verim ve saman verimi 1 Mart, 15 Mart ve 1 Nisan ekim tarihi uygulamalarından elde edilmiştir. Tohum verimi, hasat indeksi ve bin tane ağırlığında en yüksek değerler 1 Mart ekim tarihi uygulamasından elde edilmiştir. Arı otu bitkisinin ilkbahar ekim döneminde tohum amaçlı yetiştirilmesinin erken ilkbaharda yapılmasının uygun olduğu sonucuna varılmıştır. Ekim tarihi geciktikçe incelenen özelliklerden elde edilen değerler azalmıștır. İlkbaharda erken ekim ile bitkilerin vejetasyon dönemi daha uzun olmakta bu da doğrudan generatif dönemi yani tohum verimini de etkilemektedir. Sonuç olarak Bartın ili ve benzer iklim koşullarına sahip bölgelerde arı otu bitkisinin tohum amaçlı yetiştiriciliğinde mart ayının ilk haftası ile nisan ayının ilk haftası arasındaki bir tarihte ekim yapılması tavsiye edilebilir.

\section{Teşekkür}

Bu çalışma Bartın Üniversitesi Bilimsel Araştırma Projeleri Koordinatörlüğü tarafından desteklenmiştir (BAP 2012.2.65).

\section{Kaynaklar}

Anonymous 1988. SAS/STAT User's Guide. Version 6. Fourth edn. Vol.2 SAS InstuteInc.. Cary. NC. USA. 1686 p.

Genç Lermi A., Palta Ş. 2014. The Effects of Different Sowing Dates of Feedleneck (Phacelia tanacetifolia) During the Autumn and Spring Sowing Periods on the Forage Yield and Quality, Bartın Orman Fakültesi Dergisi, 16 (23-24): 1118. EISSN: 1308-5875.
Karadağ Y., Büyükburç U. 1999. Tokat Koşullarında Yetiştirilen Arıtunun (Phacelia tanacetifolia Benth.) Verim ve Adaptasyonu Üzerinde Bir Araştırma, GOÜ. Ziraat Fakültesi Dergisi, 16 (1):155-169.

Karadağ Y., Büyükburç U. 2003. Tokat Koşullarında Arı otunun (Phacelia tanacetifolia Benth.) Yazlı Ekim Zamanı Üzerinde Araştırmalar. II-Tohum Verimi İle İlgili Özelliklerin incelenmesi, GOÜ Ziraat Fakültesi Dergisi, 20 (1): 143-148.

Kızılşimşek M., Ateş F. 2004. Kahramanmaraş Şartlarında Arı otunun (Phacelia tanacetifolia Bentham) Değişik Ekim Zamanlarındaki Çiçeklenme Seyri ve Arı Merası Olarak Değerlendirilmesi. KSÜ Fen ve Mühendislik Dergisi 7(1):96-103.

Kumova U., Korkmaz A. 1998. Çukurova Bölgesinde Arı Otu (Phacelia tanacetifolia B.) Bitkisinin Bal Arısı (Apis Mellifera L.) İçin Önemi. Tigem Dergisi, ss.28-32,

Kuşvuran A., Nazlı, R. İ., Tansı, V. 2011. Türkiye'de ve Batı Karadeniz Bölgesi'nde ÇayırMera Alanları, Hayvan Varlığg ve Yem Bitkileri Tarımının Bugünkü Durumu. GOÜ, Ziraat Fakültesi Dergisi, 28(2); 21-32.

Ünal S. 2004. Yem Bitkilerinde Tohumluk Üretimi. Tarla Bitkileri Merkez Araştırma Dergisi. 13(1-2);76-82.

Soya H., Avcıŏglu R., Geren H. 2004. Yem Bitkileri Hasad Yayıncılık. 223s.

SPSS Inc., 2007. SPSS for Windows, Version 16.0. Chicago, SPSS Inc. 